\title{
EKSISTENSI DAN PERLINDUNGAN WAYANG ORANG SRIWEDARI SURAKARTA DITINJ AU DARI ASPEK HUKUM HAK CIPTA
}

\author{
Maharsidewi Kusharyani'1, Budi Santoso², Fifiana Wisnaeni³ \\ Program Studi Magister IImu Hukum \\ Fakultas Hukum Universitas Diponegoro \\ budi_tmg1@yahoo.com
}

\begin{abstract}
ABSTRAK
Wayang Orang Sriwedari Surakarta merupakan salah satu pertunjukan kesenian budaya yang harus dilestarikan dan dilindungi. Wayang Orang Sriwedari adalah ekspresi budaya tradisional atau folklor yang berhak mendapat perlindungan Hak Cipta. Wayang Orang Sriwedari Surakarta dapat dilindungi apabila pertunjukan tersebut masih tetap eksis Tujuan penelitian ini adalah untuk menganalisis eksistensi dan perlindungan Wayang Orang Sriwedari Surakarta ditinjau dari hukum Hak Cipta dan untuk mengetahui peran dan upaya-upaya yang dilakukan oleh Pemerintah Kota Surakarta untuk melestarikan dan melindungi Wayang Orang Sriwedari Surakarta. Metode penelitian yang digunakan adalah yuridis empiris yaitu meneliti data sekunder terlebih dahulu untuk kemudian meneliti data primer di lapangan. Spesifikasi penelitian yang digunakan adalah deskriptif analitis yaitu data yang diperoleh dikumpulkan, disusun, dijelaskan dan dianalisis. Hasil penelitian mengajukan bahwa Wayang Orang Sriwedari Surakarta hingga saat ini masih dapat mempertahankan eksistensinya di tengah-tengah masyarakat sebagai salah tontonan pertunjukan tradisional yang masih diminati masyarakat. Wayang Orang Sriwedari Surakarta sebagai ekspresi budaya tradisional atau folklor berhak memperoleh perlindungan hukum Hak Cipta. Unsur-unsur yang ada dalam Wayang Orang Sriwedari Surakarta yang dapat dilindungi Hak Cipta adalah berupa folklor lisan atau tulisan, musik, gerak atau tari, teater, sandiwara, pertunjukan. Peran dan upaya Pemerintah Kota Surakarta dalam melestarikan Wayang Orang Sriwedari Surakarta adalah dengan mengangkat pemain Wayang Orang Sriwedari Surakarta menjadi Pegawai Negeri Sipil dan melakukan regenerasi pemain dengan membuka rekruitmen pemain baru.
\end{abstract}

\section{Kata Kunci : Eksistensi; Hak Cipta; Perlindungan Wayang Orang Sriwedari Surakarta}

\footnotetext{
1 Mahasiswa Program Studi Magister IImu Hukum UNDIP

2 Penulis Kedua, Penulis Koresponden

3 Penulis Ketiga
} 


\section{Pendahuluan}

Indonesia adalah negara yang terdiri dari beberapa pulau yang di dalamnya terdapat berbagai macam suku dan budaya. Hasil karya seni budaya tersebut harus senantiasa dilestarikan dan dilindungi mengingat perkembangan globalisasi dunia. Salah satu hasil kreasi seni budaya masyarakat Indonesia adalah kesenian tari wayang orang Sriwedari Surakarta. Wayang Orang Sriwedari Surakarta adalah sebuah kesenian yang memadukan antara tarian, drama, dan koreografi. Wayang orang diperankan oleh manusia dan mengambil cerita yang berasal dari Ramayana dan Mahabarata sebagai induk ceritanya. Wayang Orang Sriwedari menjadi obyek penelitian karena eksistensinya hingga saat ini di tengah modernisasi zaman.

Upaya pemerintah Indonesia dalam melindungi seni budaya Indonesia salah satunya dengan diundangkannya UU No. 28 Tahun 2014 Tentang Hak Cipta, di mana kesenian budaya menjadi salah satu yang dilindungi oleh rezim Hak Cipta. Wayang Orang Sriwedari Surakarta merupakan salah satu kesenian budaya berupa folklor atau dalam UU Nomor 28 Tahun 2014 disebut sebagai ekspresi budaya tradisional yang dilindungi dan dimiliki oleh Negara sesuai dengan Pasal 38 UU Nomor 28 Tahun 2014 Tentang Hak Cipta. Pasal tersebut menjelaskan bahwa hak cipta atas ekspresi budaya tradisional dipegang oleh negara dan negara wajib menginventarisasi, menjaga dan memelihara ekspresi budaya tradisional tersebut serta dalam penggunaannya harus memperhatikan nilai-nilai yang hidup dalam masyarakat pengembannya.

Ekspresi budaya tradisional, sesuai dengan Penjelasan Pasal 38 Ayat 1 UU Nomor 28 Tahun 2014, yaitu mencakup salah satu atau kombinasi bentuk ekspresi sebagai berikut, verbal tekstual, baik lisan maupun tulisan, yang berbentuk prosa maupun puisi, dalam berbagau tema dan kandungan isi pesan, yang dapat berupa karya sastra ataupun narasi informatif; musik, mencakup antara lain, vokal, instrumental, atau kombinasinya; gerak, mencakup antara lain, tarian; teater, mencakup antara lain, pertunjukan wayang dan sandiwara rakyat; seni rupa, baik dalam bentuk dua dimensi maupun tiga dimensi yang terbuat dari berbagai macam bahan seperti kulit, kayu, bambu, logam, batu, keramik, kertas, tekstil dan lain-lain atau kombinasiya; dan upacara adat.

Wayang Orang Sriwedari Surakarta merupakan salah satu kesenian budaya yang dilindungi oleh Pemerintah. Dalam hal ini, Pemerintah Surakarta memiliki peran yang besar dalam melestarikan kesenian Wayang Orang Sriwedari. Sejarahnya, Wayang Orang Sriwedari pernah mengalami pasang dan surut dalam menyelenggarakan pertunjukan bahkan pernah hampir dilupakan oleh masyarakat. Namun, berkat kegigihan Pemerintah Surakarta dalam melestarikan kesenian tersebut, pada saat ini kesenian Wayang Orang Sriwedari hidup kembali.

Jurnal ini akan mengkaji permasalahan mengenai eksistensi perlindungan kesenian Wayang Orang Sriwedari yang dikaji melalui 
perlindungan hukum Hak Cipta, serta peran dan upaya pemerintah Surakarta dalam melestarikan kesenian Wayang Orang Sriwedari. Uraian permasalahan tersebut akan dikaji menggunakan Teori Reward (Reward Theory) dan Teori Hukum Utilitarian sebagai pisau analisis.

\section{Metode Penelitian}

Metode penelitian yang digunakan dalam jurnal ini adalah metode pendekatan penelitian yuridis empiris, yaitu penelitian yang bertujuan untuk memperoleh pengetahuan empiris dengan jalan terjun langsung ke lapangan mengenai segala sesuatu yang terkait dengan bagaimana upaya perlindungan hukum Wayang Orang Sriwedari dilihat dari aspek hukum hak cipta di Indonesia dan bagaimana upaya pemerintah kota Surakarta untuk melestarikan Wayang Orang Sriwedari. Selain itu, penelitian ini menggunakan spesifikasi penelitian deskriptif analitis, dengan menggunakan jenis data primer dan data sekunder, metode pengumpulan data melalui teknik wawancara dan studi kepustakaan. Metode analisis data yang digunakan adalah dengan memaparkan untuk kemudian disajikan secara kualitatif dalam bentuk jurnal ilmiah. Sistematika penulisan jurnal ini adalah pendahuluan, metode penelitian, pembahasan, saran dan simpulan serta daftar pustaka.

\section{Pembahasan}

\section{A. Eksistensi dan Perlindungan Hukum Wayang Orang Sriwedari Surakarta Dalam Hukum Hak Cipta}

\section{Periodisasi Eksistensi Wayang Orang Sriwedari Surakarta}

Periodisasi Eksistensi Wayang Orang Sriwedari Surakarta dapat dibagi sebagai berikut :

a. Di Bawah Keraton Kasunanan Surakarta (1901-1946)

Periodisasi eksistensi Wayang Orang Sriwedari dimulai dari tahun 1901 yaitu tahun berdirinya taman hiburan Sriwedari atau Kebon Raja dan diakhiri pada tahun 1946 yaitu periode akhir keberadan Wayang Orang Sriwedari di bawah penguasaan keraton karena hak-hak istimewa para raja Surakarta di luar tembok istana secara resmi dihapus oleh pemerintah pada tanggal 1 Juni $1946^{4}$ Wayang Orang Sriwedari mulai mengadakan pentas secara tetap di taman Sriwedari sejak tahun 1911. 5 Pada waktu itu grup wayang orang dinamakan Persatuan Wayang Wong Sriwedari.

Dari segi tata pentas, awalnya Wayang Orang Sriwedari diadakan di panggung terbuka dengan penonton berdiri di segala penjuru panggung dengan membayar tiket masuk ke dalam Taman Sriwedari, kemudian berkembang dengan dibangun panggung prosenium secara permanen. Bentuk panggung prosenium merupakan bentuk transformasi dan adaptasi tata teknik pentas model Eropa.

Perkembangan Wayang Orang Sriwedari pada periode ini sangat bergantung dengan situasi

\footnotetext{
${ }^{4}$ M.C. Ricklefs, Sejarah Indonesia Modern, (Yogyakarta: Gadjah Mada University Press, 1991), hlm. 335.

${ }^{5}$ S. Haryanto, Pratiwimba Adhiluhung Sejarah dan Perkembangan Wayang, (Jakarta: Jambatan, 1988), hlm. 86.
} 
ekonomi dan politik saat itu mengingat Indonesia sedang melawan penjajah. Konflik bersenjata pada saat perang berpengaruh pada pertunjukan Wayang Orang Sriwedari. pertunjukan Wayang Orang Sriwedari diizinkan sampai pukul 23.00 dan disertai sensor skenario serta sinopsis dari pemerintah kolonial Jepang.

b. Di Bawah Dinas Pendapatan Daerah Kotamadya Surakarta (1946-1980)

Adanya perubahan sistem pemerintahan dari penguasaan keraton ke penguasaan negara Indoneia membawa konsekuensi terhadap keberadaan Wayang Orang Sriwedari dan para anak wayang atau pemain wayang orang. Pada periode ini, status abdi dalem sebagai pegawai keraton dialihfungsikan ke status pegawai pemerintah Republik Indonesia. Secara tidak langsung pemain Wayang Orang Sriwedari memiliki dualisme keanggotaan dalam status kepegawaian.

Hasil penjualan tiket pertunjukan merupakan pemasukan bagi keuangan daerah, sedangkan pemain Wayang Orang menerima gaji sesuai dengan ketentuan yang berlaku, selain itu pertunjukan Wayang Orang Sriwedari mendapat subisdi dari pemerintah sehingga Wayang Orang Sriwedari bersifat semi komersial.

Sebagai suatu organisasi sosial, Wayang Orang Sriwedari dalam perjalanannya mengalami problematika dari waktu ke waktu. Dimensi politik, ekonomi, sosial dan psiko-kultural dapat berpengaruh terhadap keberadaan Wayang Orang Sriwedari. Periode ini Wayang Orang Sriwedari mengalami pasang surut akibat dari keadaan ekonomi dan politik negara seperti inflasi, perubahaan keadaan politik dari Orde Lama menjadi Orde Baru. Saat itu, Wayang Orang Sriwedari mengalami kemunduran akibat dari gagalnya regenerasi pemain dan perkembangan teknologi dan ilmu pengetahuan yang tidak memberi manfaat pada seni pertunjukan tradisional.

c. Di Bawah Dinas Pariwisata Kotamadya Surakarta (1980-1991)

Pada periode ini, Wayang Orang Sriwedari dikelola oleh Seksi Objek Wisata dan Pramuwisata Khusus. Tanggung jawab Dinas Pariwisata meliputi dukungan dana pembiayaan produksi, gaji seluruh pemain dan staf wayang orang dan biaya pemeliharaan gedung beserta seluruh fasilitasnya.

Peningkatan seni Wayang Orang Sriwedari dilakukan melalui kerjasama dengan sekolahsekolah seni di Surakarta dan Yogyakarta. Peningkatan kesejahteraan ekonomi pemain juga dilakukan untuk peningkatan mutu pemain melalui pemberian dana insentif Presiden dan pengangkatan pemain Wayang Orang Sriwedari sebagai Pegawai Negeri Sipil pada tahun 1986.

Pada periode ini Wayang Orang Sriwedari mengalami kemunduran dengan ditandai adanya krisis penonton, hal ini disebabkan dari mutu sarana dan prasarana Wayang Orang Sriwedari yang kurang baik dan tata cara publikasi yang kurang inovatif untuk menarik penonton.

Grafik jumlah penonton Wayang Orang Sriwedari pada tahun 1980 hingga 1991 mengalami pasang surut, hal tersebut jelas berpengaruh pada pemasukan daerah dari penjualan tiket, bahkan 
dapat dikatakan bahwa pemerintah mengalami defisit keuangan untuk pembiayaaan Wayang orang Sriwedari. Dengan demikian jelas bahwa pertunjukan Wayang Orang Sriwedari tidak lagi bersifat komersial tetapi sistem pengelolaan Wayang Orang Sriwedari lebih bersifat pemeliharaan dan pelestarian bentuk kesenian tradisional.

\section{d. Pasca Bantuan Dana Pemerintah Jepang} (1994-2004)

Periode ini, semakin banyak hiburan yang masuk ke Indonesia akibat dari perkembanga teknologi seperti teknologi rekaman dan acara televisi yang semakin beragam. Pada awal tahun 1994 pemerintah Jepang memberi bantuan dana peningkatan sarana dan prasarana gedung pertunjukan sebesar satu milyar rupiah melalui Kedutaan Besar Jepang sebagai upaya untuk menarik minat penonton. Peningkatan sarana dan prasarana dilakukan dengan merehabilitasi gedung, fasilitas tata cahaya, tata suara dan dilengkapi dengan penyejuk ruangan. Peresmian gedung dilakukan pada tanggal 24 Desember 1994 yang ditandatangani oleh Taizo Watanabe selaku Duta Besar Jepang dan R. Hartomo selaku Walikota Surakarta atas nama pemerintah Indonesia. ${ }^{6}$

Pada tahun 1998 terjadi Gerakan Reformasi yang dilakukan oleh mahasiswa. Gerakan reformasi secara tidak langsung juga mengubah pola pikir pemain Wayang Orang Sriwedari untuk mengemas pertunjukan Wayang Orang Sriwedari menjadi lebih

\footnotetext{
${ }^{6}$ Ibid., hlm. 227.
}

modern mengikuti pola kebutuhan masyarakat tanpa keluar dari pakem-pakem yang ada. Perubahan dilakukan pada pertunjukan Wayang Orang Sriwedari dalam kaitannya dengan konsep garap pertunjukan, unsur-unsur wayang orang, garap gerak tari Wayang Orang Sriwedari, garap rias dan busana, serta karawitan iringan Wayang Orang Sriwedari.

Wayang Orang Sriwedari mulai mengubah konsep pertunjukannya seperti durasi waktu pertunjukan menjadi 2-3 jam dan melahirkan lakonlakon baru yang lebih menarik tanpa merubah pakem-pakem yang ada untuk menarik minat penonton dan disesuaikan dengan perkembangan zaman atau kebutuhan penonton saat itu.

e. Di Bawah Dinas Kebudayaan dan Pariwisata Kota Surakarta (2004-2015)

Pemerintah Kota Surakarta sebagai pengelola melakukan berbagai cara untuk mempertahankan eksistensi Wayang Orang Sriwedari Surakarta diantaranya mengangkat para pemain wayang menjadi Pegawai Negeri Sipil (PNS) serta melakukan regenerasi pemain dengan membuka lowongan kerja sebagai pemain wayang dengan status Tenaga Kerja Kontrak. Jumlah total pemain Wayang Orang Sriwedari Surakarta saat ini adalah 68 (enam puluh delapan) orang, 34 (tiga puluh empat) orang diantaranya adalah berstatus sebagai Pegawai Negeri Sipil (PNS) dan 34 (tiga puluh empat) orang lainnya berstatus sebagai Tenaga Kerja Kontrak. ${ }^{7}$

\footnotetext{
7 Data absensi pemain Wayang Orang Sriwedari Surakarta
} 
Pemerintah Kota Surakarta di bawah Dinas Kebudayaan dan Pariwisata Kota Surakarta juga memberikan dukungan dana melalui pemberian dan pemeliharaan fasilitas gedung pertunjukan, busana pentas dan tata rias, serta melakukan renovasi gedung untuk pemeliharaan. Biaya pemeliharaan dan gaji para pemain Wayang Orang Sriwedari Surakarta berasal dari APBD Kota Surakarta.

Strategi lain yang dilakukan untuk mempertahankan eksistensi Wayang Orang Sriwedari Surakarta adalah dengan melakukan inovasi dan kreatifitas yang berasal dari improvisasi para pemain wayang. Inovasi juga dilakukan dengan pembuatan naskah drama wayang orang yang mengambil ide dari perkembangan zaman saat ini sehingga melahirkan lakon-lakon baru, cerita atau lakon tersebut sering disebut sebagai lakon carangan, yaitu lakon karangan baru yang dikaitkan dengan lakon pakem yaitu cerita Mahabarata dan Ramayana. ${ }^{8}$ Cerita atau lakonlakon baru tersebut diharapkan dapat menarik minat penonton.

Pada saat ini, berdasarkan jumlah penonton Wayang Orang Sriwedari Surakarta saat ini sudah mendapatkan eksistensinya kembali, walaupun dahulu penonton sangat banyak dan menjadi primadona, namun setidaknya saat ini telah mendapatkan pencapaiannya kembali setelah

\footnotetext{
${ }^{8}$ B. Waluyo, Analisis Penyebab Kemunduran Wayang Orang Sriwedari, etd.repository.ugm.ac.id/.../S1-2014301690-Introduction, diakses pada tanggal 15 Oktober 2015 pada pukul 15.45 WIB
}

terpuruk dan kehilangan minat penonton. Wayang Orang Sriwedari Surakarta tampil pada hari Senin hingga Sabtu pada pukul 20.00 - 22.30. Tiket untuk sekali pertunjukan adalah Rp. 3000,- per-orang.

\section{Perlindungan Hukum Wayang Orang Sriwedari Surakarta Dalam Hukum Hak Cipta}

Wayang Orang Sriwedari Surakarta merupakan salah satu bentuk kesenian budaya di Surakarta berupa pertunjukan tari dan drama yang dimainkan oleh sekumpulan orang yang merupakan personifikasi dari wayang kulit purwa. Wayang Orang Sriwedari Surakarta digolongkan sebagai folklor atau ekspresi budaya tradisional ${ }^{9}$ yang harus dilindungi.

Pertunjukan Wayang Orang Sriwedari Surakarta dapat dimasukkan sebagai ekspresi budaya tradisional kelompok seni dan sastra karena berupa sebuah pertunjukan drama, tari dan naskah drama diambil dari cerita dalam epos Mahabarata atau Ramayana, selain itu Wayang Orang Sriwedari Surakarta merupakan budaya kesenian yang turun temurun, bersifat holistik yang tidak dapat dipisahkan dari masyarakat yang membangunnya serta merupakan jalan hidup (way of life) yang digunakan oleh komunitas masyarakat yang penuh dengan nilai kehidupan.

Wayang Orang Sriwdari Surakarta dilindungi oleh Undang-Undang Nomor 28 Tahun 2014

\footnotetext{
${ }^{9}$ Ekspresi budaya tradisional merupakan seni atau kebudayaan masyarakat yang telah turun-temurun dan umumnya tidak diketahui siapa penciptanya, kebudayaan itu baik berupa sebuah seni, sastra atau ilmu pengetahuan.
} 
Tentang Hak Cipta. Pasal tersebut mengatur bahwa ekspresi budaya tradisional, dilindungi dan dimiliki oleh Negara, selain itu negara wajib menginventarisasi, menjaga dan memelihara ekspresi budaya tradisional tersebut serta dalam penggunaannya harus memperhatikan nilai-nilai yang hidup dalam masyarakat pengembannya. Penjelasan Pasal 38 Ayat 1 UU Nomor 28 Tahun 2014, yaitu mencakup salah satu atau kombinasi bentuk ekspresi sebagai berikut : verbal tekstual, baik lisan maupun tulisan, yang berbentuk prosa maupun puisi, dalam berbagai tema dan kandungan isi pesan, yang dapat berupa karya sastra ataupun narasi informatif; musik, mencakup antara lain, vokal, instrumental, atau kombinasinya; gerak, mencakup antara lain, tarian; teater, mencakup antara lain, pertunjukan wayang dan sandiwara rakyat; seni rupa, baik dalam bentuk dua dimensi maupun tiga dimensi yang terbuat dari berbagai macam bahan seperti kulit, kayu, bambu, logam, batu, keramik, kertas, tekstil dan lain-lain atau kombinasiya; dan; upacara adat."

Berdasarkan uraian Penjelasan Pasal 38 Ayat 1 UU No. 28 Tahun 2014 di atas, maka dalam Wayang Orang Sriwedari Surakarta yang dapat dilindungi oleh hukum hak cipta, yaitu pada bagian:

a. Verbal tekstual (lisan dan tulisan)

Unsur folklor lisan atau tulisan dalam Wayang Orang Sriwedari Surakarta yang dapat dilindungi oleh Hak Cipta adalah cerita Mahabarata dan Ramayana, walaupun kedua cerita tersebut berasal dari India, namun cerita yang berkembang di Jawa adalah cerita yang telah ditransformasikan dan diadaptasi sesuai dengan kehidupan masyarakat Jawa. Pengadaptasian cerita juga dilakukan dengan membuat cerita atau lakon-lakon baru yang berbeda dari cerita Ramayana atau Mahabarata. Naskah cerita atau lakon-lakon baru yang sering disebut dengan lakon carangan inilah yang dapat dilindungi oleh Hak Cipta karena naskah cerita tersebut murni dibuat oleh sutradara dengan mengambil ide cerita dari perkembangan kehidupan masyarakat jawa saat ini baik berhubungan dengan kehidupan sosial maupun politik.

b. Musik

Musik dalam pertunjukan Wayang Orang Sriwedari Surakarta adalah berupa gendhing yaitu kerangka lagu atau kesatuan tangga nada yang membentuk alunan nada dengan menggunakan alat musik tradisional gamelan. Bentuk gendhing yang digunakan dalam wayang orang disusun dalam struktur pathet yang macamnya meliputi bentuk gendhing lancaran, sampak, srepegan, ayak-ayakan, kemuda, ketawang, ladrang dan bentuk merong ketuk loro kerep yang divariasi dengan suara vokal yang berupa tembang. Setiap gendhing menggambarkan situasi yang berbedabeda seperti situasi bahagia, sedih atau dalam situasi agung. Gendhing-gendhing tersebut merupakan kerangka lagu dan yang membuat lagu adalah sindenan, gerongan dengan menggunakan alat musik seperti rebah, gender atau gambang.

c. Gerak (tarian)

Gerak tarian atau tari memiliki definisi sebagai gerak yang indahyang disusun dengan baik untuk menciptakan harmonisasi dan keselarasan irama, 
dilakukan dengan penjiwaan makna yang terkandung dalam tarian. 10 Unsur tari yang ada dalam pertunjukan Wayang Orang Sriwedari Surakarta adalah berasal dari tarian istana Mangkunegaran yang telah mengalami penyederhanaan motif gerak, namun dalam pelaksanaan gerak tarian yang ada dalam Wayang Orang Sriwedari Surakarta harus tetap mengikuti aturan atau norma yang disebut sebagai patrap beksa dan hastha sawanda. Gerak tari tersebut menggunakan gerak tari tipe Surakarta yang memilki perwatakan tari yang sedikit berbeda dengan gerak tari Yogyakarta.

Unsur-unsur gerak tari dalam Wayang Orang Sriwedari Surakarta yang dapat dilindungi Hak Cipta adalah gerak atau tarian gaya Surakarta yang digunakan dalam Wayang Orang Sriwedari Surakarta, seperti merak ngigel, sata ngetap swiwi, kukila tumilang, branjangan ngumbara, mundhing mangundha, wreksa sol, anggiri gora, pucang kanginan, sikatan met boga, ngangrang bineda.

d. Teater (pertunjukan wayang dan sandiwara rakyat)

Wayang Orang Sriwedari Surakarta merupakan sebuah pertunjukan teater yang berisi sandiwara dan tarian yang penuh dengan nilai-nilai budaya tradisional. Unsur-unsur yang mendukung keberhasilan pementasan Wayang Orang Sriwedari diantaranya adalah berkaitan dengan bentuk panggung, durasi lamanya pertunjukan, lakon dan

\footnotetext{
${ }^{10}$ Artikel oleh R. Tria, Kajian Teori Ketrampilan Menari diambil melalui http://eprints.uny.ac.id/9523/3/bab\%20208209241004.pdf pada 3 Januari 2016 pukul 11.33.
}

cerita-cerita yang dibawakan serta tata busana dan tata rias.

Bentuk perkembangan wayang orang yang tadinya murni sebagai pertunjukan keraton menjadi pertunjukan komersial di luar keraton mengalami transformasi yang disesuaikan dengan selera dan kebutuhan masyarakat, salah satunya adalah bentuk tata teknik pentas menggunakan model panggung prosenium. ${ }^{11}$ Bentuk panggung prosenium merupakan bentuk panggung Eropa yang ditransformasi dan diadaptasikan di Indonesia.

Hingga saat ini, Wayang Orang Sriwedari Surakarta telah menciptakan ratusan lakon yang telah dimainkan diantaranya adalah Parta Krama, Petruk Dadi Ratu, Kangsa Adu Jago, Kikis Tunggarana, Wahyu Cakraningrat, Anoman Duta, Rama Tambak dan sebagainya. Lakon-lakon yang dibawakan secara garis besar dapat dibedakan dalam kategori cerita pakem, cerita carangan dan cerita sempalan. ${ }^{12}$

Tata busana yang digunakan dalam pertunjukan Wayang Orang Sriwedari Surakarta merupakan tata busana sebagai personifikasi dari penggambaran tokoh yang ada dalam wayang kulit. Tata busana didukung dengan tata rias untuk memperkuat gambaran tokoh yang dimainkan. Tata rias wayang orang dikategorikan sebagai tata rias karakter, tata rias tersebut disesuaikan dengan

\footnotetext{
${ }^{11}$ Hersapandi, op.cit., hlm. 8 dan 90.

${ }^{12}$ Agus Prasetyo, Koordinator serta pemain Wayang Orang Sriwedari Surakarta, wawancara, (Surakarta: 1 Desember 2015)
} 
karakterisasi tokoh yang dibawakan yang mengacu pada karakterisasi wayang kulit.

Berdasarkan uraian di atas mengenai unsurunsur dalam pertunjukan sandiwara Wayang Orang Sriwedari Surakarta yang dapat dilindungi oleh Hak Cipta sesuai dengan ketentuan yang ada dalam UU No. 28 Tahun 2014 tentang Hak Cipta adalah lakon-lakon baru yang berasal dari cerita yang diambil dari ide kehidupan masyarakat Jawa saat ini, serta busana atau tata rias yang dipakai untuk menunjang pertunjukan wayang. Busana dan tata rias tersebut menggambarkan sifat atau karakter lakon yang diperankan.

\section{B. Peran dan Upaya Pemerintah Kota Surakarta Dalam Melestarikan dan Melindungi Wayang Orang Sriwedari Surakrta}

1. Peran Pemerintah Kota Surakarta dalam Melestarikan dan Melindungi Wayang Orang Sriwedari Surakarta

Peran pemerintah Kota Surakarta dalam melestarikan dan melindungi Wayang Orang Sriwedari Surakarta dapat diuraikan berdasarkan kewenangan, tugas dan kewajiban Kota Surakarta sebagai pemerintahan daerah yang bersifat otonom atau daerah otonom. ${ }^{13}$

\footnotetext{
${ }^{13}$ Daerah Otonom adalah kesatuan masyarakat hukum yang mempunyai batas-batas wilayah yang berwenang mengatur dan mengurus Urusan Pemerintahan dan kepentingan masyarakat setempat menurut prakarsa sendiri berdasarkan aspirasi masyarakat dalam sistem Negara Kesatuan Republik Indonesia, Pasal 1 Angka 12 UU No. 23 Tahun 2014 Tentang Pemerintahan Daerah.
}

Kota Surakarta memliki kebebasan untuk menjalankan otonomi seluas-luasnya, termasuk untuk mengelola, mengatur dan mengurus sumber daya alam, sumber daya manusia dan potensipotensi yang ada dalam wilayah Kota Surakarta, kecuali urusan pemerintahan yang oleh undangundang ditentukan sebagai urusan Pemerintah Pusat sebagaimana diatur dalam Pasal 18 ayat (5) UUD NRI 1945. Pemerintah Kota Surakarta berperan untuk melestarikan dan melindungi Wayang Orang Sriwedari Surakarta, maka Pemerintah Kota Surakarta mendapat kewenangan atas kebudayaan dan pariwisata yang tercantum dalam Pasal 12 ayat (2) huruf $p$ dan Pasal 12 ayat (3) huruf b UU No. 23 Tahun 2014 Tentang Pemerintahan Daerah. Peran Pemerintah Kabupaten atau Kota dalam sub urusan kebudayaan adalah sebagai berikut : 14

a. Pengelolaan kebudayaan yang masyarakat pelakunya dalam daerah kabupaten/kota.

b. Pelestarian tradisi yang masyarakat penganutnya dalam daerah kabupaten/kota.

c. Pembinaan lembaga adat yang penganutnya dalam daerah kabupaten/kota.

Selanjutnya peran Pemerintah Kabupaten/Kota dalam sub urusan kesenian tradisional adalah melakukan pembinaan yang masyarakat pelakunya dalam daerah kabupaten/kota. 15

\footnotetext{
${ }^{14}$ lihat seterusnya pada Lampiran UU No. 23 Tahun 2014 Tentang Pemerintahan Daerah.

${ }^{15}$ ibid.
} 
Peran Pemerintah Kabupaten/Kota dalam sub urusan destinasi pariwisata adalah sebagai berikut $: 16$

a. Pengelolaan daya tarik wisata kabupaten/kota.

b. Pengelolaan kawasan strategis pariwisata kabupaten/kota.

c. Pengelolaan destinasi pariwisata kabupaten/kota.

d. Penetapan tanda daftar usaha pariwisata kabupaten/kota.

Selain itu, peran Pemerintah Kabupaten/Kota dalam sub urusan pengembangan ekonomi kreatif melalui pemanfaatan dan perlindungan Hak Kekayaan Intelektual adalah penyediaan prasarana (zona kreatif/ruang kreatif/kota kreatif) sebagai ruang berekspresi, berpromosi dan berinteraksi bagi insan kreatif di daerah Kabupaten atau kota.

Terakhir adalah peran Pemerintah Surakarta dalam sub urusan pengembangan sumber daya pariwisata dan ekonomi kreatif yaitu dengan pelaksanaan peningkatan kapasitas sumber daya manusia pariwisata dan ekonomi kreatif tingkat dasar. ${ }^{17}$

Dengan begitu, dapat disimpulkan bahwa peran Pemerintah Kota Surakarta dalam melestarikan dan melindungi Wayang Orang Sriwedari Surakarta adalah sebagai pengelola, subyek yang bertanggungjawab dalam pelestarian, subyek yang bertanggungjawab dalam pemasaran pariwisata, penyedia sarana dan prasarana dan subyek yang melakukan pembinaan dan juga

\footnotetext{
${ }^{16}$ Ibid.

${ }^{17}$ Ibid.
}

berperan sebagai pembuat kebijakan dalam kaitan untuk melindungi kesenian dan kebudayaan yang ada di Pemerintahan Kota Surakarta, khususnya Wayang Orang Sriwedari Surakarta.

\section{Upaya Pemerintah Kota Surakarta dalam Melestarikan dan Melindungi Wayang Orang \\ Sriwedari Surakarta}

Pemerintah Kota Surakarta fokus dalam upaya untuk melestarikan Wayang Orang Sriwedari Surakarta, hal tersebut dapat dilihat dari upayaupaya yang dilakukan oleh Pemerintah Kota Surakarta yaitu membuat kebijakan untuk mengangkat pemain Wayang Orang Sriwedari Surakarta menjadi Pegawai Negeri Sipil, hal tersebut dilakukan sejak tahun $1986 .{ }^{18}$ Saat ini dari keseluruhan jumlah pemain Wayang Orang Sriwedari Surakarta, 34 (tiga puluh empat) orang diantaranya telah berstatus sebagai Pegawai Negeri Sipil (PNS) Surakarta di bawah Dinas Kebudayaan dan Pariwisata Kota Surakarta. ${ }^{19}$

Zaman modern saat ini, tantangan berat yag dihadapi adalah regenarasi pemain Wayang Orang Sriwedari Surakarta. Upaya yang dilakukan Pemerintah Kota Surakarta dalam kaitannya dengan regenerasi pemain adalah dengan membuka rekruitmen pemain-pemain baru Wayang Orang Sriwedari Surakarta. Rekruitmen tersebut bekerja sama dengan Badan Kepegawaian Daerah Kota Surakarta untuk mencari pemain-pemain baru Wayang Orang Sriwedari Surakarta dengan status

\footnotetext{
${ }^{18}$ Hersapandi, op.cit., hlm. 122.

${ }^{19}$ Data Absensi Pemain Wayang Orang Sriwedari Surakarta
} 
sebagai Tenaga Kerja Kontrak dengan gaji sesuai dengan Upah Minimum Regional (UMR) Kota Surakarta. Saat ini terdapat 34 pemain Wayang Orang Sriwedari Surakarta yang berstatus sebagai Tenaga Kerja Kontrak. ${ }^{20}$

Kebijakan Pemerintah Kota Surakarta untuk mengangkat pemain Wayang Orang Sriwedari Surakarta menjadi Pegawai Negri Sipil dan Tenaga Kerja Kontrak dengan tujuan untuk membantu kesejahteraan ekonomi para pemain Wayang Orang Sriwedari Surakarta sekaligus melestarikan dan menjaga eksistensi Wayang Orang Sriwedari Surakarta di tengah zaman modern saat ini.

Upaya lain yang dilakukan Pemerintah Kota Surakarta adalah salah satunya dengan mengikutsertakan Wayang Orang Sriwedari dalam berbagai kegiatan atau acara di Kota Surakarta dan menjadikan Wayang Orang Sriwedari Surakarta sebagai kelompok kesenian yang struktur organisasinya berada di bawah Dinas Kebudayaan dan Pariwisata Kota Surakarta.

\section{Simpulan dan Saran}

\section{Simpulan}

\section{A. Eksistensi dan Perlindungan Wayang Orang}

\section{Sriwedari Surakarta}

Eksistensi Wayang Orang Sriwedari Surakarta dapat dilihat dari perkembangan dan eksistensi Wayang Orang Sriwedari Surakarta di tengah masyarakat.. Eksistensi tersebut dapat dilihat hingga saat ini Wayang Orang Sriwedari Surakarta masih tetap melakukan pertunjukan setiap hari dan menampilkan pertunjukan dengan lebih baik.

Perlindungan hukum hak cipta dapat diberikan kepada Wayang Orang Sriwedari selama pertunjukan seni budaya tersebut masih eksis dan memiliki fungsi tertentu di dalam masyarakat. Wayang Orang Sriwedari dapat mempertahankan eksistensinya hingga saat ini bahkan menjadi salah satu ikon wisata budaya di kota Surakarta, maka Wayang Orang Sriwedari Surakarta layak mendapatkan perlindungan hukum Hak Cipta.

Perlindungan Hak Cipta yang diberikan adalah sesuai dengan Pasal 38 Ayat 1 UU No. 28 Tahun 2014 tentang Hak Cipta. Unsur-unsur dari pertunjukan Wayang Orang Sriwedari Surakarta yang dapat dilindungi oleh Hak Cipta adalah sebagai berikut :

1) Folklor lisan atau tulisan, berupa cerita pakem Mahabarata dan Ramayana, serta cerita carangan yang dibuat sesuai dengan perkembangan zaman saat ini.

2) Musik, berupa aransemen lagu berupa gendhing yang dimainkan dengan alat musik tradisional gamelan.

3) Gerak atau tarian, berupa keseluruhan gerak yang masuk dalam tari tradisional bentuk Surakarta.

4) Teater, pertunjukan atau sandiwara, berupa lahirnya lakon-lakon baru, tata busana dan tata rias yang keseluruhannya mendukung jalannya pentas pertunjakan Wayang orang Sriwedari Surakarta.

\footnotetext{
${ }^{20}$ Ibid.
} 


\section{B. Peran dan Upaya Pemerintah Surakarta dalam melestarikan dan melindungi Wayang orang Sriwedari Surakarta}

Peran Pemerintah kota Surakarta dalam hal ini Dinas Kebudayaan dan Pariwisata Kota Surakarta dalam melestarikan dan melindungi Wayang Orang Sriwedari Surakarta adalah sebagai pengelola, pihak yang mempromosikan Wayang orang Sriwedari Surakarta, pihak yang memberikan fasilitas, pembina dan pembuat kebijakan.

Upaya-upaya yang telah dilakukan Pemerintah Kota Surakarta dalam melestarikan dan melindungi Wayang Orang Sriwedari Surakarta adalah mengangkat pemain Wayang Orang Sriwedari Surakarta sebagai Pegawai Negeri Sipil, regenerasi pemain Wayang orang Sriwedari Surakarta, mengikutsertakan Wayang orang Sriwedari Surakarta dalam berbagai acara di Surakarta, menjadikan Wayang Orang Sriwedari Surakarta sebagai kelompok kesenian yang struktur organisasinya berada di bawah Dinas Kebudayaan dan Pariwisata Kota Surakarta.

\section{Saran}

Saran yang dapat disampaikan adalah Pemerintah Kota Surakarta hendaknya segera membuat peraturan daerah Kota Surakarta yang mengatur mengenai perlindungan folklor yang berupa intangible seperti salah satunya kesenian Wayang orang Sriwedari Surakarta, hal ini dikarenakan folklor merupakan warisan budaya yang wajib untuk dilestarikan dan dilindungi keberadaannya.
Pemerintah Kota Surakarta hendaknya segera melakukan inventarisasi budaya-budaya di Kota Surakarta yang dapat masuk dalam katagori folklor atau ekspresi budaya tradisional sesuai dengan UU No. 28 Tahun 2014 tentang Hak Cipta, sehingga budaya-budaya tersebut tercatat sebagai budaya daerah yang telah dilindungi oleh Hak Cipta. Hal tersebut untuk menghindari hal-hal buruk seperti misal negara lain mengklaim budaya tersebut sebagai budaya negaranya.

\section{Daftar Pustaka}

B. Waluyo, Analisis Penyebab Kemunduran Wayang Orang Sriwedari, etd.repository.ugm.ac.id/.../S1-2014-301690Introduction, diakses pada tanggal 15 Oktober 2015 pada pukul 15.45 WIB

Hersapandi, Wayang Wong Sriwedari: Dari Seni Istana Menjadi Seni Komersial, (Yogyakarta: Yayasan Untuk Indonesia, 199).

M.C. Ricklefs, Sejarah Indonesia Modern, (Yogyakarta: Gadjah Mada University Press, 1991.

S. Haryanto, Pratiwimba Adhiluhung Sejarah dan Perkembangan Wayang, (Jakarta: Jambatan, 1988.

R. Tria, Kajian Teori Ketrampilan Menari diambil melalui http://eprints.uny.ac.id/9523/3/bab\%20208209241004.pdf pada 3 Januari 2016 pukul 11.33. 
Jurnal Law Reform

Volume 12, Nomor 1, Tahun 2016

Agus Prasetyo, Koordinator serta pemain Wayang

Orang Sriwedari Surakarta, wawancara, (Surakarta: 1 Desember 2015)

UU No. 23 Tahun 2014 Tentang Pemerintahan Daerah.

Data absensi pemain Wayang Orang Sriwedari Surakarta
Program Studi Magister Ilmu Hukum Fakultas Hukum Universitas Diponegoro 